American Journal of Pharmacology and Toxicology 3 (1): 19-29, 2008

ISSN 1557-4962

(C) 2008 Science Publications

\title{
tNOX (ENOX2) Target for Chemosensitization-Low-Dose Responses in the Hormetic Concentration Range
}

\author{
${ }^{1}$ D. James Morre, ${ }^{2}$ Sara Dick, ${ }^{1}$ Elena Bosneaga, ${ }^{1}$ Andrew Balicki, ${ }^{2}$ L.Y. Wu, \\ ${ }^{1}$ Nicole McClain and ${ }^{2}$ Dorothy M. Morre \\ ${ }^{1}$ Departments of Medicinal Chemistry and Molecular Pharmacology, \\ ${ }^{2}$ Department of Foods and Nutrition, \\ Purdue University, West Lafayette, Indiana, USA
}

\begin{abstract}
An emerging concept of cancer chemotherapy is that of chemosensitization. Most often applied to the treatment of drug-resistance cancers, chemosensitization has utility when such cancers are rendered drug sensitive through treatment with the sensitizing agent. A particularly striking example of chemosensitization is that encountered with the synthetic isoflavene phenoxodiol where patients with taxane- and/or platinum-resistant ovarian carcinoma once again become sensitive to these drugs following treatment with phenoxodiol. The latter appears to be a true chemosensitization in that the phenoxodiol need not be co-administered with the taxane or platinum drugs. Sensitivity is retained many weeks after the phenoxodiol has been cleared from the system. The response appears to be mediated through the primary drug target of phenoxodiol, a cancer-specific cell surface ECTO-NOX or ENOX protein designated tNOX (ENOX2). The ENOX protein family has been previously recognized as a hormetic target. The hypothesis under investigation is that chemosensitization and low dose synergies are most obvious in the hormetic range of concentrations and that the two phenomena, hormesis and chemosensitization, may be related mechanistically.
\end{abstract}

Key words: ECTO-NOX, NADH oxidase, cancer, phenoxodiol, sulforaphane, paclitaxel, cisplatin, HeLa cells, ovarian carcinoma

\section{INTRODUCTION}

Hormesis is a dose-response phenomenon characterized by low-dose stimulation and a high-dose inhibition (Fig. 1) ${ }^{[1,2]}$. Hormesis is most often observed in the context of a dose-time-response framework where the maximum low-dose stimulation is typically not more than $30-60 \%$ greater than that without $\operatorname{drug}^{[3,4]}$.

Among the mechanisms published that can account for specific hormetic dose responses is that of the ECTO-NOX (ENOX) proteins ${ }^{[5,6]}$. The ECTO-NOX proteins represent a closely-related group of cell surface proteins involved in growth. One member of the group, tNOX or ENXO2, is characteristic of neoplasia in general and may be responsible for the hormetic or synergistic responses to chemosensitizing drugs targeted to tNOX.

ECTO-NOX/ENOX proteins (for cell surface $\mathrm{NADH}$ oxidases including isoforms) are cell surface hydroquinone on NADH oxidases with protein disulfide

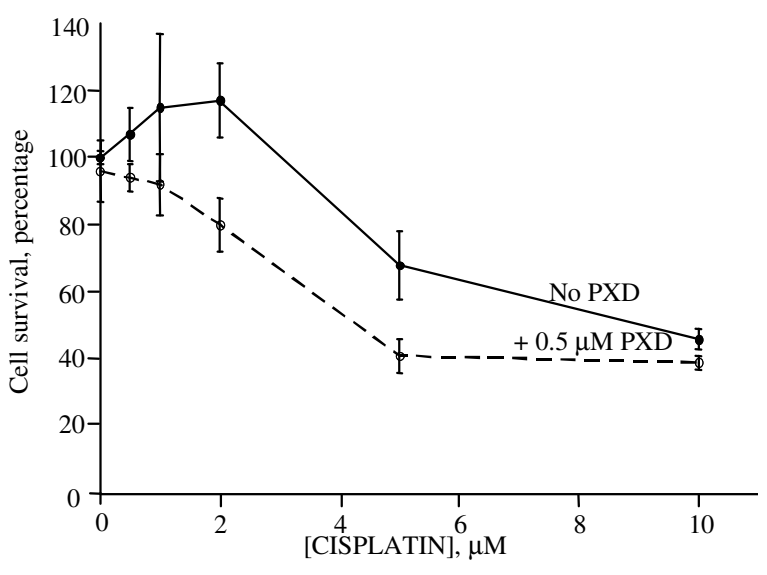

Fig. 1: Dose response of $\mathrm{CP}-70$ cells to $\log$ concentration of cisplatin co-administered with $0.5 \mu \mathrm{M}$ phenoxodiol (PXD) compared to no phenoxodiol after $72 \mathrm{~h}$. Values with nonoverlapping standard deviations were significantly different $(\mathrm{p}<0.001$

Corresponding Author: D. James Morre, Department of Medicinal Chemistry and Molecular Pharmacology, Purdue University, 201 S. University Street, West Lafayette, IN 47907-2064 USA Tel: 765-494-1388 Fax: 765-494-4001 
thiol interchange activity ${ }^{[7,8]}$. tNOX (for tumor associated ECTO-NOX) is specific to the surfaces of cancer cells ${ }^{[7,9]}$. tNOX proteins are normally drug responsive and are inhibited by various anti tumor drugs and substances such as adriamycin ${ }^{[10]}$, the cancerfighting principal of green tea, (-)-epigallocatechin gallate $(\mathrm{EGCg})^{[11]}, \quad$ capsaicin $^{[9]}, \quad$ anti-tumor sulfonylureas ${ }^{[12]}$, cisplatinum, antitumor quassinoids, antitumor acetogenins ${ }^{[7]}$, the synthetic isoflavene phenoxodiol $^{[13]}$ and the anticancer principle from broccoli, sulforaphane (unpublished). The activity is normally resistant to inhibition by taxanes such as paclitaxel $^{[14]}$. Paclitaxel, together with cisplatin, is important to therapy and chemoprevention of breast and ovarian cancers ${ }^{[15,16]}$. Sulforaphane is an attractive agent, as well, due to its well established anticancer effects and low toxicity ${ }^{[17]}$. Phenoxodiol, targeted specifically to tNOX ${ }^{[13]}$, is in Phase III clinical trials for ovarian cancer $^{[18]}$. The constitutive ENOX, CNOX or ENOX1, is drug resistant (i.e., unaffected by sulforaphane, phenoxodiol or other tNOX inhibitors) and is found associated with the surfaces of both cancer and non-cancer cells ${ }^{[8]}$.

The cancer specificity of cell surface tNOX is strongly supported by several lines of evidence. A drug responsive tNOX activity has been rigorously determined to be absent from plasma membranes of non-transformed human and animal cells and tissues ${ }^{[9]}$. The tNOX proteins lack a transmembrane binding domain $^{[19]}$ and are released from the cell surface by brief treatment at low $\mathrm{pH}^{[20]}$. A drug-responsive tNOX activity has not been detected in sera from healthy volunteers or patients with diseases other than cancer $^{[21,22]}$. Several tNOX antisera have identified the immunoreactive band at $34 \mathrm{kDa}$ (the processed molecular weight of one of the cell surface forms of tNOX associated with cancer cells and tissues). The band is absent with Western blot analyses or immunoprecipitation when using non-transformed cells and tissues or sera from healthy volunteers or patients with disorders other than cancers as antigen source ${ }^{[19,23,24]}$. Those antisera include a monoclonal antibody ${ }^{[24]}$, single-chain variable region fragment $(\mathrm{scFv})$ recombinant antibody derived from DNA of the monoclonal hybridoma ${ }^{[24]}$, polyclonal antisera to expressed $\mathrm{tNOX}^{[24]}$ and polyclonal peptide antisera to the conserved adenine nucleotide binding region of $\mathrm{tNOX}^{[24]}$.

tNOX (ENOX2) cDNA has been cloned (GenBank Accession No. AF207881 ${ }^{[24]}$, US Patent Publication 2003-0207340 A1). The derived molecular weight from the open reading frame is $70.1 \mathrm{kDa}$. Identified functional motifs include a quinone binding site, an adenine nucleotide binding site and a CXXXXC cysteine pair as a potential protein disulfide-thiol interchange site based on site-directed mutagenesis ${ }^{[24]}$. Based on available genomic information ${ }^{[25]}$ the tNOX gene is located on chromosome $\mathrm{X}$ and it is comprised of thirteen exons.

\section{MATERIALS AND METHODS}

Phenoxodiol (PXD) was from Marshall Edwards, 140 Wicks Road, North Ryde, Australia. All other chemicals were from Sigma or from suppliers indicated.

Growth of cells. Cells were grown in culture in a humidified atmosphere of $5 \% \mathrm{CO}_{2}$ in air at $37^{\circ} \mathrm{C}$. Media were renewed every 4 to 7 days.

HeLa (ATCC CCL-2) human cervical adenocarcinoma cells were cultured in minimal essential medium with Earles salts and $2 \mathrm{mM} \mathrm{L-}$ glutamine (Gibco) with $10 \%$ fetal bovine serum (heatinactivated) plus $50 \mathrm{mg} \mathrm{L}^{-1}$ gentamycin sulfate.

CP-70, cis platinum-resistant human ovarian cancer cells, were obtained courtesy of Gil Mor, Yale University.

Spectrophotometric assay of NADH oxidase: NADH oxidase activity was determined as the disappearance of $\mathrm{NADH}$ measured at $340 \mathrm{~nm}$ in a reaction mixture containing $10^{6} \mathrm{HeLa}$ or CP-70 cells as indicated for each table and figure in $50 \mathrm{mM}$ Tris-MES ( $\mathrm{pH} 7.0)$, $0.2 \mathrm{mM} \mathrm{KCN}$ to inhibit mitochondrial oxidase activity and $150 \mu \mathrm{M} \mathrm{NADH}, 100 \mu \mathrm{M}$ GSH, $0.03 \% \mathrm{H}_{2} \mathrm{O}_{2}$ at $37^{\circ} \mathrm{C}$ with temperature control $\left( \pm 0.5^{\circ} \mathrm{C}\right)$ and stirring ${ }^{[24]}$. Activities were measured using paired Hitachi U3210 spectrophotometers. Assays were initiated by addition of NADH with duplicate assays for $5 \mathrm{~min}$ each to determine dose-response. A millimolar extinction coefficient of 6.22 was used to determine specific activity.

For discrimination between CNOX and tNOX, assays were for $1 \mathrm{~min}$ and were repeated on the same sample every $1.5 \mathrm{~min}$ for the times indicated. CNOX activity was constitutive, resistant to drug inhibition and exhibited an oscillatory pattern with a period length of 24 min. tNOX activity was tumor cell-specific, normally drug inhibited or was responsive to chemosensitization and exhibited an oscillatory pattern with a period length of $22 \mathrm{~min}$.

$\mathrm{NADH}$ is an impermeant substrate and ECTONOX proteins are the only known sources of NADH oxidase activity with intact cells. $\mathrm{KCN}(0.2 \mathrm{mM})$ is added as well but is largely without effect suggesting that cell breakage to release internal NADH oxidases into the assay is negligible. 
Growth measurements: HeLa cell growth was determined using a 96-well plate assay in which cells were fixed by glutaraldehyde and stained with $0.5 \%$ aqueous crystal violet. The absorbance was determined at $580 \mathrm{~nm}$ using an automated plate reader.

Equilibrium binding: Paclitaxel as paclitaxel-2(2Benzoyl-Ring-UL- $\left.{ }^{14} \mathrm{C}\right)(52.3 \mathrm{mCi} / \mathrm{mmol})$ was obtained from Sigma (St. Louis, MO) and diluted with ethanol. For binding studies, a multi-cell rotating Teflon cell equilibrium dialyser (Spectrum Equilibrium Dialyzer, Spectrum Medical Instruments, Los Angeles, CA) with a dialyzing volume of $1 \mathrm{ml}$ and a $47 \mathrm{~mm}$ diameter membrane (12 to $14 \mathrm{kDa}$ molecular mass cutoff) was used as described. ${ }^{[13]}$ The dialysis membranes were prepared by soaking in water for $30 \mathrm{~min}$ followed by $30 \%$ ethanol for $30 \mathrm{~min}$ and several changes of distilled water. Both sides of the chamber were supplied with $0.5 \mathrm{ml}$ final volume of $50 \mathrm{mM}$ Tris $\mathrm{HCl}$. To one side of the changer were added the paclitaxel in ethanol and the fraction to be evaluated. An equivalent amount of ethanol was added to the opposite side of the chamber and equilibrium established by rotating the cells at about $100 \mathrm{rpm}$ at $25^{\circ} \mathrm{C}$ overnight. A $100 \mu \mathrm{L}$ sample was withdrawn from each chamber and radioactivity was determined at the $99 \%$ confidence level by liquid scintillation spectrometry. Determinations were in triplicate to increase the confidence of specific highaffinity binding to approximately $\pm 5 \%$. Experiments were in duplicate.

\section{RESULTS AND DISCUSSIN}

Inhibition of tNOX activity: Cancer cells (HeLa and CP-70) contain both the constitutive ECTO-NOX form (ENOX1 or CNOX) and a cancer-related ECTO-NOX form (ENOX2 or tNOX). The activity of CNOX, the constitutive ECTO-NOX form, is resistant to cisplatin and paclitaxel for both cell lines (Table 1). The activity was unaffected by these drugs at concentrations as high as $100 \mu \mathrm{M}$ in the assay. When assayed under reducing conditions, the $\mathrm{EC}_{50}$ for inhibition of $\mathrm{tNOX}$ by phenoxodiol was $200 \mathrm{nM}$ Table 1.

To assay for chemosensitization, the cells were first treated with phenoxodiol and then the phenoxodiol was removed by washing. Following the phenoxodiol washout, inhibition by phenoxodiol was no longer evident (drug reversibly bound). Addition of cisplatin or paclitaxel to the phenoxodiol pretreated and washed cells resulted in an enhanced inhibition with the $\mathrm{EC}_{50}$ for paclitaxel or cisplatin reduced to $50 \mathrm{nM}$ Table 1 . CNOX was unresponsive to either cisplatin or paclitaxel and responsiveness of CNOX to cisplatin or
Table 1: Response of tNOX activity of HeLa and CP-70 cells to phenoxodiol, cisplatin and paclitaxel alone or in combination. $\mathrm{EC}_{50}$ was estimated from rate measurements at five concentrations over the range $10 \mathrm{nM}$ to $100 \mu \mathrm{M}$ compared to no drug as described. ${ }^{[26]}$ Estimates of $\mathrm{EC}_{50}$ within this range from duplicate determinations varied less than 2-fold except where indicated

\begin{tabular}{lll}
\hline & $\mathrm{EC}_{50}$ & \\
& $-\mathrm{HeLa}$ & $\mathrm{CP}-70$ \\
\hline Drug & $200 \mathrm{nM}$ & $20 \mathrm{nM}$ \\
\hline Phenoxodiol & $>100 \mu \mathrm{M}$ & $>100 \mu \mathrm{M}$ \\
Paclitaxel & $100 \mathrm{nM}$ & $>1000 \mathrm{nM}$ \\
Cisplatin & $>1000 \mathrm{nM}$ & $>1000 \mathrm{nM}$ \\
Trans-platinum & $0.1-2.5 \mu \mathrm{M}$ & $1 \mu \mathrm{M}$ \\
Pre-treat with $10 \mu \mathrm{M}$ phenoxodiol for & & \\
60 min, then add cisplatin (no wash) & & \\
Pre-treat with $10 \mu \mathrm{M}$ phenoxodiol for $60 \mathrm{~min}$ & $<50 \mathrm{nM}$ & $<100 \mathrm{nM}$ \\
wash to remove drug, then add cisplatin & & \\
$\begin{array}{l}\text { Pre-treat with } 10 \mu \mathrm{M} \text { phenoxodiol for } \\
60 \text { min, then add paclitaxel (no wash) }\end{array}$ & $>100 \mu \mathrm{M}$ & $1 \mu \mathrm{M}$ \\
$\begin{array}{l}\text { Pre-treat with } 10 \mu \mathrm{M} \text { phenoxodiol, } \\
\text { wash to remove drug, then add paclitaxel }\end{array}$ & $<50 \mathrm{nM}$ & $<50 \mathrm{nM}$ \\
\hline
\end{tabular}

Table 2: Response of growth of CP-70 cells to 0.5 or $1 \mu \mathrm{M}$ phenoxodiol and to $1 \mu \mathrm{M}$ cisplatin alone and in combination. Chemosensitization was enhanced by removal of phenoxodiol after $48 \mathrm{~h}$ and replacement by cisplatin in the absence of phenoxodiol

\begin{tabular}{llll}
\hline & & \multicolumn{2}{l}{ (\%) Inhibition of } \\
Growth & \\
Treatment & & $48 \mathrm{~h}$ & $72 \mathrm{~h}$ \\
\hline Phenoxodiol alone & $0.5 \mu \mathrm{M}$ & $22 \pm 5$ & $21 \pm 6$ \\
& $1.0 \mu \mathrm{M}$ & $40 \pm 5$ & $45 \pm 9$ \\
Cisplatin alone & $1.0 \mu \mathrm{M}$ & $40 \pm 6$ & $60 \pm 6$ \\
Phenoxodiol+cisplatin & $0.5+1 \mu \mathrm{M}$ & $26 \pm 4$ & $43 \pm 7$ \\
& $1.0+1 \mu \mathrm{M}$ & $32 \pm 7$ & $50 \pm 4$ \\
Phenoxodiol, remove after & $0.5+1 \mu \mathrm{M}$ & $60 \pm 4^{*}$ & $71 \pm 2^{*}$ \\
48 h and replace with cisplatin & $1.0+1 \mu \mathrm{M}$ & $74 \pm 11^{*}$ & $88 \pm 6^{*}$ \\
\hline
\end{tabular}

*: Significantly different from cisplatin alone $\mathrm{p}<0.001$

paclitaxel was not observed to result from phenoxodiol pretreatment.

Cisplatin or paclitaxel inhibition of tNOX activity by phenoxodiol pretreatment was augmented by removal of the phenoxodiol prior to cisplatin or paclitaxel addition. The chemosensitization response was reduced, however, when the two drugs were added together or cisplatin or paclitaxel were added after phenoxodiol in series with the phenoxodiol still show in Table 1. Co-administration of the drugs frequently was antagonistic Table 1.

Chemosensitization of cell growth: The above findings were reproduced in growth experiments for both CP-70 Table 2 and HeLa cells ${ }^{[27]}$. For CP-70 cells, phenoxodiol at 0.5 or $1 \mu \mathrm{M}$ followed by $1 \mu \mathrm{M}$ cisplatin gave augmented growth inhibition only with sequential application where the phenoxodiol was removed prior 
Am. J. Pharm. \& Toxicol., 3 (1): 19-29, 2008

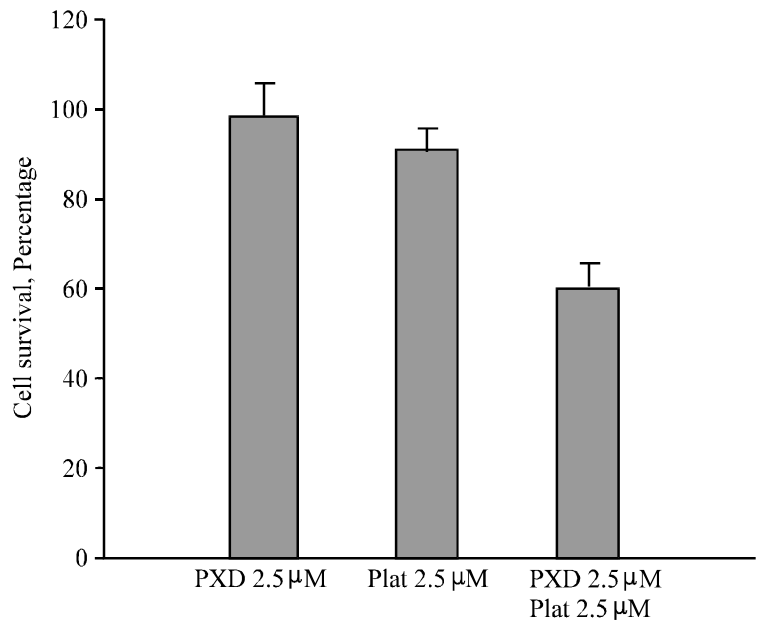

Fig. 2: Restoration of sensitivity of CP-70 cells to cisplatin (plat) by co-administration with $2.5 \mu \mathrm{M}$ phenoxodiol (PXD) and compared to $2.5 \mu \mathrm{M}$ cisplatin after $48 \mathrm{~h}(\mathrm{p}<0.001)$

to the addition of cisplatin (compare with Fig. 1 and 2). However, in the presence of $0.5 \mu \mathrm{M}$ phenoxodiol, the response to cisplatin on the growth of CP-70 human ovarian carcinoma cells in culture was enhanced as well in the concentration range of 2 to $5 \mu \mathrm{M}$ by coadministration compared to no phenoxodiol (Fig. 1 and 2). In the absence of phenoxodiol, $2 \mu \mathrm{M}$ cisplatin exhibited a typical hormetic stimulation of between 20 and $30 \%$. However, this stimulation was ablated by the presence of $0.5 \mu \mathrm{M}$ phenoxodiol as a major contributor to efficacy enhancement by coadministration at $2 \mu \mathrm{M}$.

Results with paclitaxel and growth of CP-70 cells were similar (Fig. 3). In the absence of phenoxodiol, 3 and $5 \mathrm{nM}$ paclitaxel stimulated growth by about $10 \%$ on average. However, the $\mathrm{EC}_{50}$ was reached at approximately $5 \mathrm{nM}$ paclitaxel in the presence of phenoxodiol whereas the absence of phenoxodiol about $20 \mathrm{nM}$ paclitaxel was required to reach the $\mathrm{EC}_{50}$.

Co-administration with phenoxodiol enhances efficacy of sulforaphane with both CP-70 and HeLa cells in culture. Growth responses of HeLa and CP-70 cells in the hormetic range of concentrations for phenoxodiol and sulforaphane are illustrated in Fig. 4. After $48 \mathrm{~h}$, the growth of CP-70 cells was inhibited by $15 \pm 3 \%$ with $0.5 \mu \mathrm{M}$ phenoxodiol (Fig. 4A). Phenoxodiol at $0.1 \mu \mathrm{M}$ was without effect. Similarly, sulforaphane was largely without effect over the concentration range 0.025 to $1 \mu \mathrm{M}$ (Fig. 4B). However, when the sulforaphane was combined with the $0.5 \mu \mathrm{M}$ concentration of phenoxodiol, there was a significantly

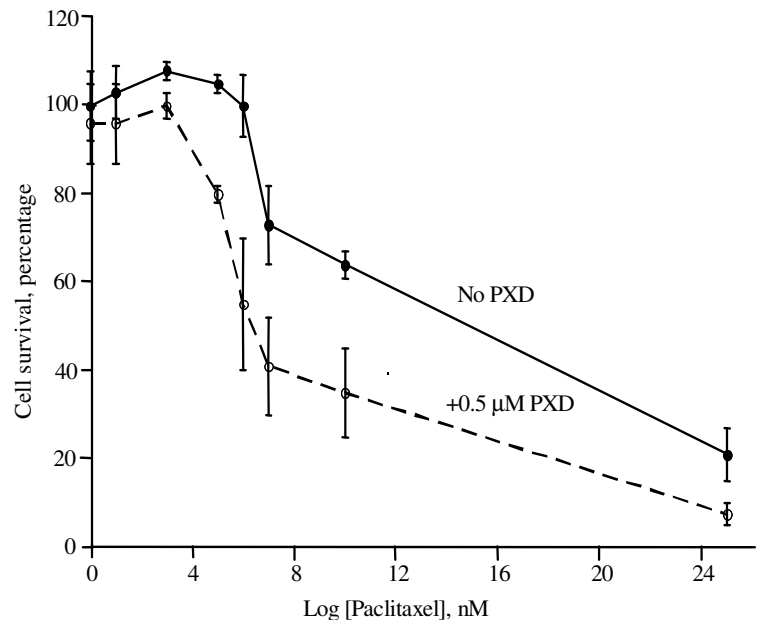

Fig. 3: Dose response of CP-70 cells to log concentration of paclitaxel co-administered with $0.5 \mu \mathrm{M}$ phenoxodiol (PXD) compared to no phenoxodiol after $72 \mathrm{~h}$. Values with nonoverlapping standard deviations were significantly different $(\mathrm{p}<0.001, \mathrm{p}<0.005$ for $3 \mathrm{nM}$ and $\mathrm{p}<0.02$ for $25 \mathrm{nM}$ )

greater inhibition over the concentration range of 0.05 to $1 \mu \mathrm{M}$ than in its absence (Fig. $4 \mathrm{C}$ ).

With HeLa cells, $0.5 \mu \mathrm{M}$ phenoxodiol inhibited by $20 \pm 8 \%$ after $48 \mathrm{~h}$ of growth (Fig. 4D). Again sulforaphane was largely without effect over the entire range from 0.05 to $2.5 \mu \mathrm{M}$ (Fig. 4E). When combined with $0.5 \mu \mathrm{M}$ phenoxodiol, inhibitions by sulforaphane were significantly enhanced compared to no phenoxodiol (Fig. 4F). With $0.1 \mu \mathrm{M}$ phenoxodiol, growth was stimulated between 0.1 and $1 \mu \mathrm{M}$ sulforaphane rather than inhibited (Fig. 4F). A similar stimulation was not seen with the CP-70 cells at $48 \mathrm{~h}$ (Fig. 4C).

Sequential addition of phenoxodiol and sulforaphane at low concentrations resulted in growth inhibitions greater than with coadministration: As with phenoxodiol, an enhancement of the response to cisplatin was seen with HeLa cells when the sulforaphane treatment was followed by removal of the sulforaphane prior to cisplatin addition (Table 3). The effect was most pronounced when the sulforaphane was followed immediately by the cisplatin. If the cisplatin was added 24 after the removal of sulforaphane, the response was considerably attenuated. Transplatinum was without effect. With CP70 cells, similar responses were observed although less pronounced than with HeLa cells. 
Am. J. Pharm. \& Toxicol., 3 (1): 19-29, 2008

Table 3: Chemosensitization by $1 \mu \mathrm{M}$ sulforaphane of response of HeLa and CP-70 cells to cisplatin comparing co-administration and administration of the cisplatin following a sulforaphane pretreatment. Growth after $72 \mathrm{~h}$ in a 96 well assay format. Averages of three experiments \pm standard deviations

\begin{tabular}{lllll}
\hline $0-24 \mathrm{~h}$ & $24-48 \mathrm{~h}$ & $48-72 \mathrm{~h}$ & $\begin{array}{l}\text { Co-administration } \\
\text { pretreatment* }\end{array}$ & $\begin{array}{l}\text { (\%) Inhibition } \\
\text { of growth }\end{array}$ \\
\hline HeLa & No addition & No addition & & $10 \pm 5$ \\
$1 \mu \mathrm{M}$ sulforaphane & $0.5 \mu \mathrm{M}$ cisplatin & No addition & & $12 \pm 4$ \\
No addition & $0.5 \mu \mathrm{M}$ cisplatin & No addition & $42 \pm 2$ & $54 \pm 6$ \\
$1 \mu \mathrm{M}$ sulforaphane & No addition & $0.5 \mu \mathrm{M}$ cisplatin & $18 \pm 6$ & $28 \pm 1$ \\
$1 \mu \mathrm{M}$ sulforaphane & No addition & $0.5 \mu \mathrm{M}$ cisplatin & $5 \pm 5$ & $4 \pm 4$ \\
No addition & No addition & No addition & & $5 \pm 4$ \\
CP-70 & $5 \mu \mathrm{M}$ cisplatin & No addition & & $20 \pm 8$ \\
$1 \mu \mathrm{M}$ sulforaphane & $5 \mu \mathrm{M}$ cisplatin & No addition & $52 \pm 2$ & $60 \pm 1$ \\
No addition & No addition & $5 \mu \mathrm{M}$ cisplatin & $28 \pm 2$ & $39 \pm 4$ \\
$1 \mu \mathrm{M}$ sulforaphane & No addition & $5 \mu \mathrm{M}$ cisplatin & $9 \pm 4$ & $16 \pm 5$ \\
$1 \mu \mathrm{M}$ sulforaphane & No addition & & & \\
\hline
\end{tabular}

*: After $24 \mathrm{~h}$, the media containing sulforaphane was removed and replaced with fresh media lacking sulforaphane before addition of cisplatin. For co-administration, the cisplatin was added to the sulforaphane-containing medium with no change of media. Inhibitions with sulforaphane pretreatment were significantly greater than inhibitions for co-administration $(\mathrm{p}<0.04$ for HeLa and $\mathrm{p}<0.01$ for CP-70)

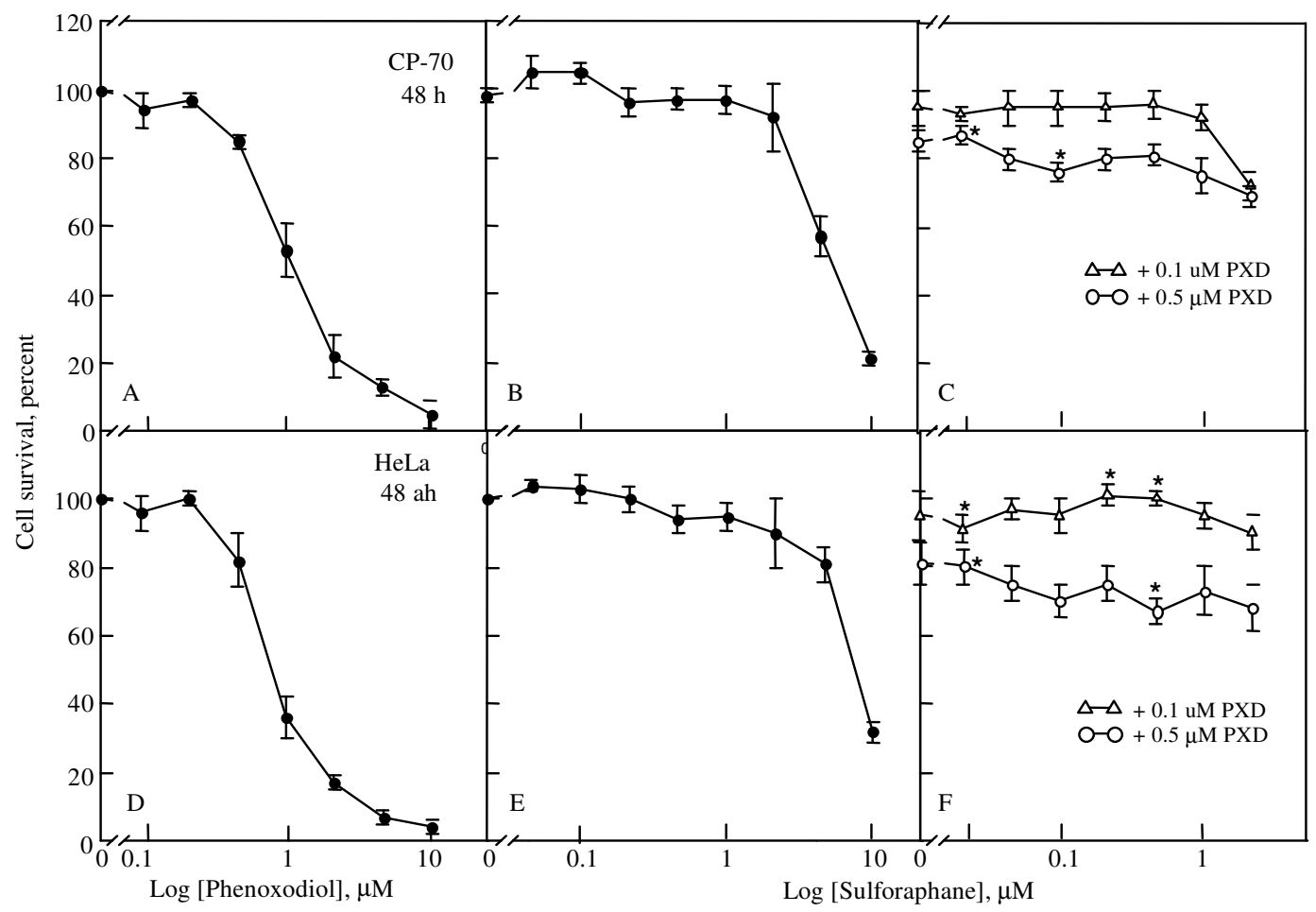

Fig. 4: Growth response of CP-70 (A-C) or HeLa (D-F) cells to phenoxodiol alone (A, D), sulforaphane alone (B,E) or sulforaphane co-administered with either $0.1 \mu \mathrm{M}$ phenoxodiol (PXD) (solid line and symbols) or $0.5 \mu \mathrm{M}$ phenoxodiol (PXD) open symbols and dashed lines (C,F). Growth was measured after $48 \mathrm{~h}$ of growth. Values are averages of 5 experiments \pm standard deviations. Values marked with asterisks were significantly different $(\mathrm{p}<0.003)$

Sulforaphane chemosensitization of response to cisplatin correlated with altered drug responsiveness of tNOX: In previous studies, the phenoxodiol chemosensitization of response of $\mathrm{CP}-70$ and HeLa cells to cisplatin and/or paclitaxel was traced to a increased drug responsiveness of cell surface tNOX in response to the phenoxodiol. ${ }^{[27]}$ The procedure for assignment of drug inhibitions specifically to tNOX 
Am. J. Pharm. \& Toxicol., 3 (1): 19-29, 2008

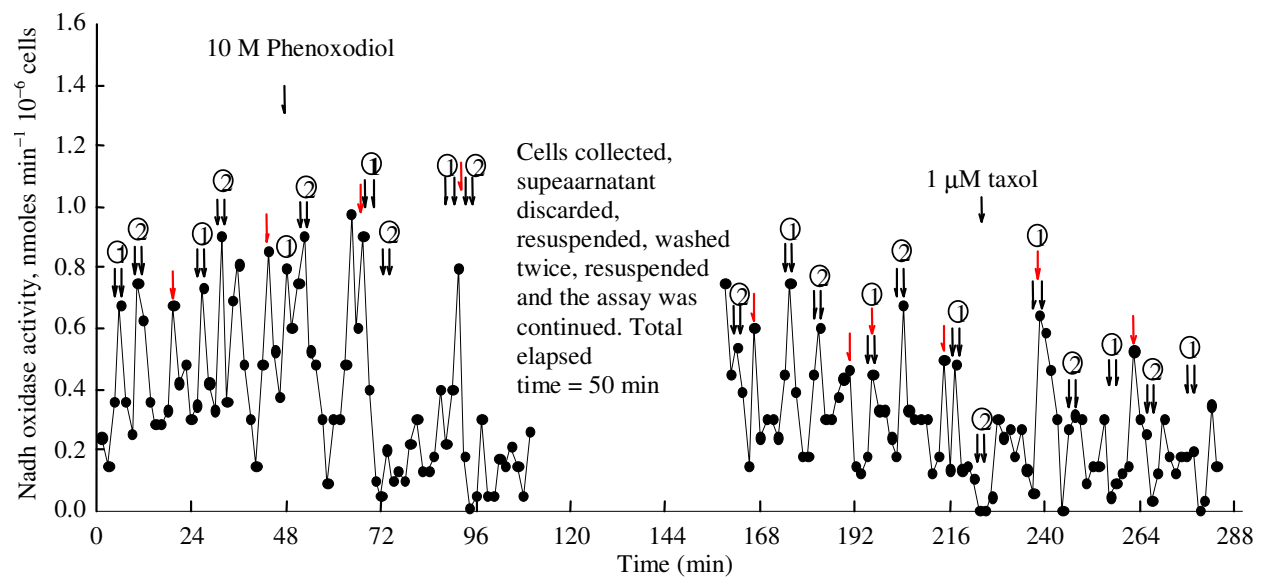

Fig. 5: Oxidation of NADH with intact HeLa cells. $10 \mu \mathrm{M}$ phenoxodiol was added after $45 \mathrm{~min}$. At 111 min the phenoxodiol was removed and the cells collected by centrifugation. The supernatant was discarded. The cells were washed through two more centrifugation resuspension cycles (total elapsed time $50 \mathrm{~min}$ ), resuspended in fresh assay medium containing substrate and the assay was continued for 60 min after which $1 \mu \mathrm{M}$ paclitaxel was added and the assay was continued for an additional $60 \mathrm{~min}$. Single arrows correspond to activity maxima of the constitutive ECTO-NOX form with maxima separated by 24 min (CNOX or ENOX1). Two additional oscillations with maxima at intervals of approximately $22 \mathrm{~min}$ correspond to tNOX (double arrows labeled (1) and (2)). With paclitaxel addition, both (1) and (2) were inhibited

takes advantage of the periodic nature of the activity (as illustrated in Fig. 5 for phenoxodiol) and a paclitaxel and a reproducible and precise difference in period length between tNOX (22 min) and CNOX (24 min). Additionally in these experiments, drug-resistant ENOX1 or CNOX was represented by a single dominant maximum (single arrows) whereas the normally drug-responsive tNOX was represented by two maxima separated in time by about 6 min (double arrows). In the example of Fig. 5 with cells, both activities were present initially. Following addition of $10 \mu \mathrm{M}$ phenoxodiol, tNOX activity was reduced but CNOX was unaffected.

After $90 \mathrm{~min}$ the cells were collected by centrifugation, washed three times over $50 \mathrm{~min}$ and resuspended in fresh assay buffer after which the assay of enzymatic activity was resumed. Following the wash out, CNOX activity remained unchanged and still in phase. tNOX activity was restored and also still in phase. Apparently the phenoxodiol was reversibly bound and was removed by washing. However, a subsequent addition of paclitaxel now resulted in a strong inhibition of tNOX activities but had no effect on the constitutive CNOX. Inhibition of tNOX with no effect on CNOX also was seen when the paclitaxel was replaced by cisplatin. Neither cisplatin nor paclitaxel were inhibitory in the absence of the phenoxodiol pretreatment and response of co-addition of phenoxodiol and paclitaxel or cisplatin were much less pronounced (not shown).

The experiment of Fig. 5 was repeated with sulforaphane instead of phenoxodiol with a similar outcome. In both CP-70 and in HeLa cells, tNOX activity was resistant to cisplatin at $1 \mu \mathrm{M}$ (Fig. $6 \mathrm{~A}, \mathrm{C}$ ). However, if the cells were first treated with sulforaphane for $60 \mathrm{~min}$ and the sulforaphane removed by centrifuging the cells and washing them three times in buffer (wash, $60 \mathrm{~min}$ ), the sulforaphane inhibition of the tNOX activity was reversed while the CNOX activity was unaffected (Fig. 6B and D). If these CP-70 or HeLa cells previously treated for $1 \mathrm{~h}$ with $1 \mu \mathrm{M}$ sulforaphane with the sulforaphane then removed were subsequently treated with $1 \mu \mathrm{M}$ cisplatin, cisplatin inhibition was then observed in these formerly cisplatin resistant cells (Fig. 6B and D). The CNOX activity, on the other hand, was still not affected. Thus, with both HeLa and CP-70 cells in culture, sulforaphane appeared to exert a chemosensitization effect on tNOX activity not unlike that observed with phenoxodiol.

Capsol-T, a green tea and Capsicum mixture, did not result in chemosensitization. In experiments similar to those of Fig. 5, no chemosensitization was seen with a commercially available mixture of green tea concentrate and Capsicum powder, Capsol- $\mathrm{T}$, that normally inhibits ENOX2 (Table 4). 
Table 4: Lack of a chemosensitization by Capsol-T of response of HeLa and CP-70 cells to cisplatin comparing co-administration and administration of the cisplatin following a Capsol-T pretreatment. Growth after $72 \mathrm{~h}$ in a 96 well assay format. Averages of three experiments \pm standard deviations. There was no significant augmentation as a result of combining Capsol-T and cisplatin

\begin{tabular}{|c|c|c|c|c|}
\hline $0-24 \mathrm{~h}$ & $24-48 \mathrm{~h}$ & $48-72 \mathrm{~h}$ & $\begin{array}{l}\text { Co-administration } \\
\text { Pretreatment* }\end{array}$ & $\begin{array}{l}\text { (\%) Inhibition } \\
\text { of growth }\end{array}$ \\
\hline \multicolumn{5}{|l|}{ HeLa } \\
\hline Capsol-T 1:50* & $0.5 \mu \mathrm{M}$ cisplatin & No addition & $67 \pm 3$ & $62 \pm 2$ \\
\hline Capsol-T 1:50 & No addition & No addition & $67 \pm 3$ & $74 \pm 2$ \\
\hline $\begin{array}{l}\text { No addition } \\
\text { CP-70 }\end{array}$ & $0.5 \mu \mathrm{M}$ cisplatin & No addition & $18 \pm 2$ & $30 \pm 5$ \\
\hline Capsol-T 1:20* & $5 \mu \mathrm{M}$ cisplatin & No addition & $76 \pm 4$ & $78 \pm 4$ \\
\hline Capsol-T 1:20 & No addition & No addition & $76 \pm 4$ & $78 \pm 4$ \\
\hline No addition & $5 \mu \mathrm{M}$ cisplatin & No addition & $27 \pm 3$ & $32 \pm 5$ \\
\hline
\end{tabular}

*For pretreatment, the media containing aqueous Capsol-T $(125 \mathrm{mg} / \mathrm{ml}$ diluted with water as indicated) was removed after $24 \mathrm{~h}$ and replaced with fresh media lacking Capsol-T before addition of cisplatin. For co-administration, the cisplatin was added to the Capsol-T-containing medium.

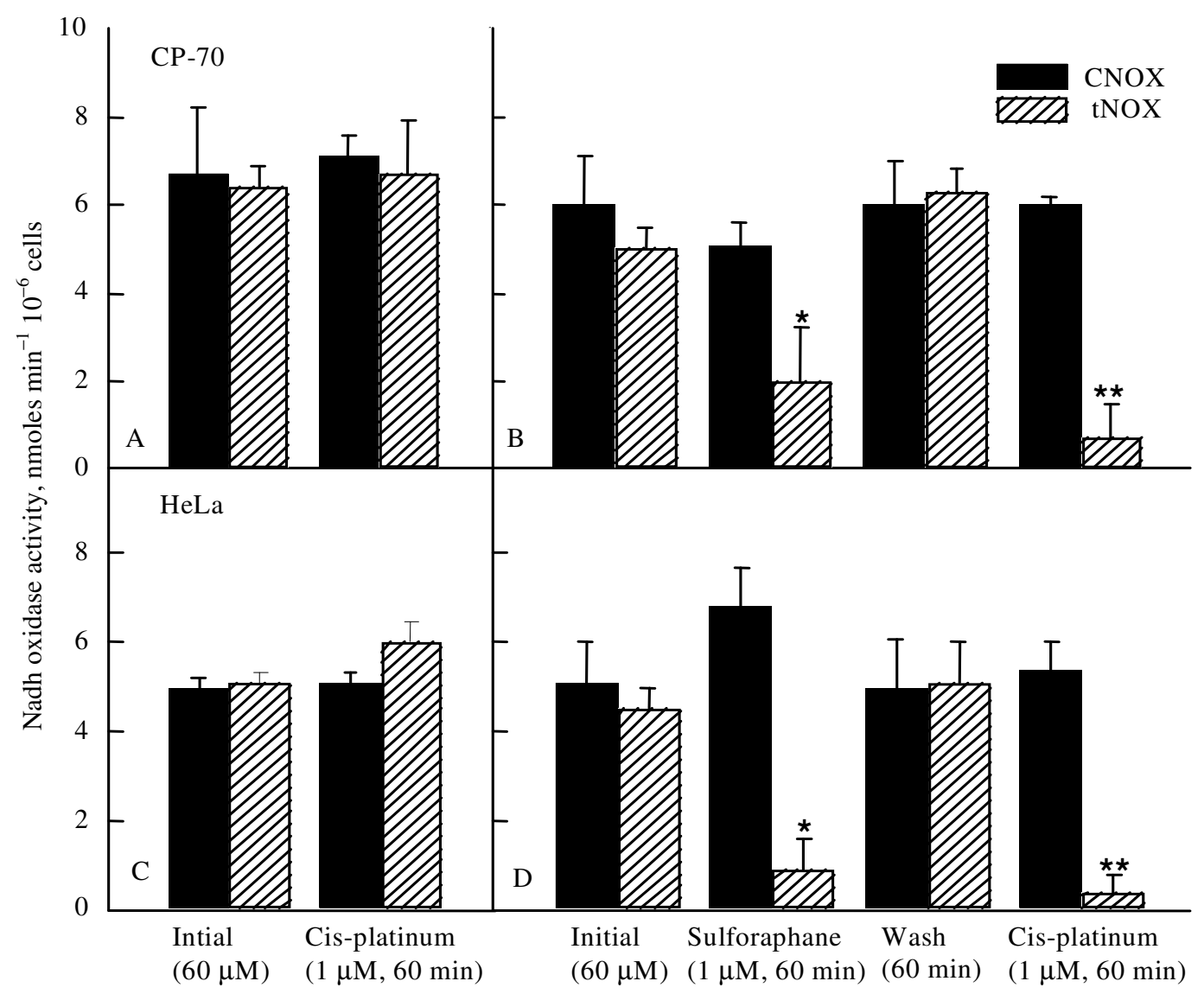

Fig. 6: Chemosensitization of cisplatin resistant ECTO-NOX activities of CP-70 and HeLa cells to cisplatin treatment by pre-treatment for $60 \mathrm{~min}$ with sulforaphane followed by several washes over $60 \mathrm{~min}$ to remove the sulforaphane $(\mathrm{B}, \mathrm{D})$. A separate series $(\mathrm{C}, \mathrm{C})$ demonstrate initial resistance to cisplatin prior to sulforaphane treatment. Values are results from 3 separate experiments \pm standard deviations among experiments. *: Significantly different from initial $(\mathrm{p}<0.01)$. **: Significantly different from initial $(\mathrm{p}<0.001)$

tNOX (ENOX2) is a cancer-specific form of the ENOX (ECTO-NOX proteins) family of growth-related and time-keeping proteins of the cell surface ${ }^{[28]}$ with both hydroquinone or NADH oxidation and protein disulfide-thiol interchange activities ${ }^{[8]}$. ENOX2 or tNOX responds to several known or suspected quinonesite inhibitors all of which have anticancer activity. ${ }^{[7]}$ All inhibit both the NADH oxidation and protein 
disulfide-thiol interchange activities of tNOX with little or no effect on either activity of $\mathrm{CNOX}^{[7,19]}$ or growth of non-cancer cells as the basis for their cancer specificity.

The protein disulfide-thiol interchange portion of the NOX cycle drives cell enlargement such that cessation of growth ${ }^{[13]}$ is followed several hours later by apoptosis as exemplified by phenoxodiol ${ }^{[31]}$. Apoptosis is the result of tNOX inhibition with similar findings for $\mathrm{EGCg}$, adriamycin, the antitumor sulfonylureas and sulforaphane. Phenoxodiol inhibits proliferation of many cancer cell lines and induces apoptosis by disrupting FLICE-inhibitory protein, FLIP, expression and by caspase-dependent and -independent degradation of the X-linked inhibitor of apoptosis XIAP. In addition, phenoxodiol sensitizes drugresistant tumor cells to anticancer drugs including paclitaxel, carboplatin and gemcitabine ${ }^{[32]}$.

Normally both CNOX and tNOX activities of HeLa cells with NADH as a substrate are unresponsive to paclitaxel (Table 1). However, if the cells were first treated with $10 \mu \mathrm{M}$ phenoxodiol for $72 \mathrm{~min}$ and then washed free of phenoxodiol, addition of $1 \mu \mathrm{M}$ paclitaxel inhibited tNOX but without effect on CNOX activity (Fig. 5). As we have observed previously ${ }^{[27]}$, activities of tNOX in the assay were inhibited by the addition of $10 \mu \mathrm{M}$ phenoxodiol but returned to the original activity level after phenoxodiol was removed. Paclitaxel $(1 \mu \mathrm{M})$ addition 72 min after washing cells (231.5 min from beginning of the experiment) inhibited tNOX activity but did not affect the activity of CNOX (activity of this protein remained constant after cells were washed). In contrast to sequential phenoxodiolpaclitaxel treatment where both tNOX activity and growth were inhibited completely by paclitaxel, phenoxodiol treatment followed by addition of paclitaxel to the phenoxodiol containing suspension resulted in paclitaxel inhibition but only to a level approximately $50 \%$ that of where the phenoxodiol was washed out prior to paclitaxel addition. The addition of $1 \mu \mathrm{M}$ paclitaxel $60 \mathrm{~min}$ after resuspension of the $\mathrm{HeLa}$ cells (260 min from beginning of the experiment) in the phenoxodiol containing solution did not affect the activity of CNOX. These findings relate to the growth experiments where sequential application of phenoxodiol followed by paclitaxel gave augmented growth inhibition whereas phenoxodiol pretreatment followed by simultaneous addition of paclitaxel was antagonistic.

Enhancement also was seen with cisplatin. Cisplatin alone inhibited the tNOX activity of HeLa cells even in the absence of phenoxodiol. However, sequential phenoxodiol followed by cisplatin treatment was more effective than cisplatin alone Table 3.

Regarding the phenomenon of chemosensitization by phenoxodiol, we have substantial evidence for HeLa cells of parallel responses between effects on tNOX activity and on cell growth. One view of the mechanism of chemosensitization is one of learning and teaching based on the prion model. For cisplatin or paclitaxel resistance, the tNOX learns not to respond to cisplatin or paclitaxel possibly through a conformational change and the altered tNOX proteins impart paclitaxel or cisplatin resistance to other tNOX molecules. To overcome the resistance, a drug-susceptible conformation must be restored to the tNOX population. Phenoxodiol and possibly also sulforaphane seem to have that capability. In fact, some degree of chemosensitization is achieved by merely adding back tNOX proteins that have been exposed to phenoxodiol $^{[27]}$.

In plants an ECTO-NOX activity is activated by the synthetic plant growth auxin regulator, 2,4dichlorophenoxyacetic acid $(2,4-D)^{[36]}$. The 2,4-Dinduced component of the ECTO-NOX activity is unregulated, resistant to proteinase $\mathrm{K}$ and leads to death of the plants. After a period of time, nearly all of the ECTO-NOX activity of 2,4-D-treated stem tissues, including most of the CNOX activity, becomes unregulated and proteinase $\mathrm{K}$ resistant through a prionlike mechanism ${ }^{[33-35]}$. tNOX also has the ability to impart proteinase $\mathrm{K}$ resistance to proteins that are normally susceptible to proteinase $\mathrm{K}$ digestion ${ }^{[33]}$. This property of tNOX, that of converting a normal form of a protein into a likeness of itself, a prion-like characteristic $^{[34,35]}$, is offered as one possible mechanism to explain phenoxodiol-and sulforaphaneinduced chemosensitization of cancer cells.

The effect of phenoxodiol in inducing paclitaxel sensitivity to tNOX at the HeLa cell surface is more difficult to explain than is the growth response to paclitaxel. tNOX normally is not inhibited by taxanes nor would tNOX be expected to bind taxanes. However, phenoxodiol appears to alter the tNOX protein to render it paclitaxel sensitive. The simplest explanation would be that somehow phenoxodiol treatment results in binding of paclitaxel by tNOX. This explanation is supported by our findings where microsome fractions enriched in plasma membranes acquire an ability to specifically bind paclitaxel $\left(\mathrm{K}_{\mathrm{d}}=0.2 \mu \mathrm{M}\right.$ by Schatchard analysis) and a finite number of apparent binding sites for phenoxodiol ${ }^{[13]}$. When incubated overnight in the presence of phenoxodiol, similar membrane preparations analyzed in parallel in the absence of 
phenoxodiol showed no evidence of specific paclitaxel binding.

Confirmation of the tNOX protein of the plasma membrane electron transport system as the primary target for phenoxodiol has recently been reported by Hearst et al. ${ }^{[37]}$ These authors investigated the effects of phenoxodiol on plasma membrane electron transport and cell proliferation in human leukemic HL60 cells and mitochondrial gene knockout $\operatorname{HL60rho(O)}$ cells that exhibit elevated plasma membrane electron transport activities. Plasma membrane electron transport was inhibited in both an $\mathrm{EC}_{50}$ of $32 \mu \mathrm{M}$ and $70 \mu \mathrm{M}$ respectively and this was associated with inhibition of cell proliferation, caspase activation and apoptosis. As in our studies ${ }^{[13]}$, proliferation of WI-38 and HUVEC cells was only weakly affected by phenoxodiol.

Reports of chemosensitization have been widespread in the literature of the past 15 to 20 years. Chemosensitization to cisplatin of oral squamous cell carcinoma cells by histone deacetylase inhibitor, suberoylanilide hydroxamic acid ${ }^{[38]}$ have been reported and by quercetin in head and neck cancer ${ }^{[39]}$. Chemosensitization has been observed with curcumin $^{[40,41]}$, and with low doses of suramin for bladder cancer to mitomycin $\mathrm{C}^{[42]}$. Augmentation of cisplatin cytotoxicity in vitro by DL-buthione sulfoxamine in resistant ovarian tumors also has been observed. ${ }^{[43]}$ A potential further source of chemo- and radiosensitization agents has been suggested to be plant polyphenols. ${ }^{[44]}$ However, our work with green tea and Capsicum has indicated that they do not behave as chemosensitizers in the same sense as observed with phenoxodiol and sulforaphane.

Reports of chemosensitization have not been limited to therapeutic drugs. SiRNA for IGFR resulted in chemosensitization to adriamycin in liver cancer cells $^{[45]}$ for example. As another example, survivingdirected antisense oligodeoxynucleotides and siRNAinduced chemosensitization of bladder cancer cells ${ }^{[46]}$. Tamoxifen is a nonsterodial antiestrogen that has been shown to reverse drug resistance in vitro in some cancer models through pathways unrelated to its antiestrogenic effects $^{[47]}$.

The above examples of chemosensitization differ from reversal of drug resistance involving the multidrug resistance transporters MDR-1-P-glycoprotein, ABCB1 and $\mathrm{ABCB} 2$ (MRP2) expressed in a variety of human cancers. Specific reversal of ABCC-2-related drug resistance in adenovirus-transduced HepG2 cells and in HepG2 tumors in nude mice expressing an ABCC2 antisense construct has been shown ${ }^{[48]}$. Reversible inhibition of P-glycoprotein by 4-chloro-N-(3((E)-3-(4- hydroxy-3-methoxyphenyl)acryloyl)phenyl)benzamide in KBV20C cells ${ }^{[49]}$ and with suramin in non-toxic doses $^{[50]}$. By overcoming the hypoxia that contributes to drug resistance in some solid cancers, low concentrations of nitric oxide mimetics that attenuate hypoxia may result in chemosensitization ${ }^{[51]}$.

In conclusion, we have demonstrated chemosensitization by phenoxodiol and sulforaphane in the hormetic range of drug concentrations that restores the ability of resistant cancer lines to respond to cisplatin or paclitaxel. Clinical evaluations of the efficacy of drug treatment protocols to treat resistant cancers based on these observations are currently in progress.

\section{REFERENCES}

1. Calabrese, E.J., 2007. Threshold dose-response model-RIP: 1911 to 2006. Bioessays, 29 (7): 686-688.

2. Southam, C.M. and J. Erlich, 1943. Effects of extracts of western red-cedar heartwood on certain wood-decaying fungi in culture. Phytopathology, 33: 517-524.

3. Calabrese, E.J. and L.A. Baldwin, 2001. The frequency of U-shaped dose-responses in the toxicological literature. Toxicol. Sci., 62: 330-338.

4. Calabrese, E.J. and L.A. Baldwin, 2003. Toxicology rethinks its central belief-Hormesis demands a reappraisal of the way risks are assessed. Nature, 421: 691-692.

5. Morré, D.J., 1998. A protein disulfide-thiol interchange protein with NADH: protein disulfide reductase (NADH oxidase) activity as a molecular target for low levels of exposure to organic solvents. Human Exptl. Toxicol., 17: 272-277.

6. Morré. D.J., 2000. Chemical hormesis in cell growth: A molecular target at the cell surface. J. Appl. Toxicol., 20: 157-163.

7. Morré, D.J., 1998. In: Plasma Membrane Redox Systems and Their Role in Biological Stress and Disease. Asard, H., A. Bérczi and R.J. Caubergs, (Eds.). Kluwer Academic Publishers, Dordrecht, pp: 121-156.

8. Morré, D.J. and D.M. Morré, 2003. Cell surface NADH oxidases (ECTO-NOX proteins) with roles in cancer, cellular time-keeping, growth, aging and neurodegenerative diseases. Free Radic. Res., 37: 795-808.

9. Morré, D.J., P.J. Chueh and D.M. Morre, 1995. Capsaicin inhibits preferentially the NADH oxidase and growth of transformed cells in culture. Proc. Natl. Acad. Sci. USA, 92: 1831-1835. 
10. Morré, D.J., C. Kim, M. Paulik, D.M. Morré and W.P. Faulk, 1997. Is the drug-responsive NADH oxidase of the cancer cell plasma membrane a molecular target for adriamycin? J. Bioenerg. Biomembr., 29: 269-280.

11. Morré, D.J., A. Bridge, L.Y. Wu and D.M. Morré, 2000. Preferential inhibition by (-)epigallocatechin-3-gallate of the cell surface NADH oxidase and growth of transformed cells in culture. Biochem. Pharmacol., 60: 937-946.

12. Morré, D.J., L.Y. Wu and D.M. Morré, 1995. The antitumor sulfonylurea N-(4methylphenylsulfonyl)-N'-(4-chlorophenyl) urea (LY181984) inhibits NADH oxidase activity of HeLa plasma membranes. Biochim. Biophys. Acta, 1240: 11-17.

13. Morre, D.J., P.J. Chueh, K. Yagiz, A. Balicki, C. Kim and D. M. Morre, 2007. ECTO-NOX target for the anticancer isoflavene phenoxodiol. Oncol. Res., 16: 299-312.

14. Chueh, P.J., L.Y. Wu, D.M. Morre and D.J. Morré, 2004. tNOX is both necessary and sufficient as a cellular target for the anticancer actions of capsaicin and the green tea catechin (-)epigallocatechin-3-gallate. BioFactors, 20:235-249.

15. Holmes, F.A., R.S. Walters, R.L. Theriault, A.D. Forman, L.K. Newton, M.N. Raber, A.U. Buzdar, D.K. Frye and G.N. Hortobagyi, 1991. Phase II trial of Paclitaxel, an active drug in the treatment of metastatic breast cancer. J. Natl. Cancer Inst., 83: 1797-1805.

16. McGuire, W.P., E.K. Rowinsky, N.B. Rosenshein, F.C. Grumbine, D.S. Ettinger, D.K. Armstrong and R.C. Donehower, 1989. Paclitaxel: a unique antineoplastic agent with significant activity in advanced ovarian epithelial neoplasms. Ann. Int. Med., 111 (4): 273-279.

17. Matsui, T.A., Y. Sowa, T. Yoshida, H. Murata, M. Horinaka, M.M. Wakada, R. Nakanishi, T. Sakabe, T. Kubo and T. Sakai, 2006. Sulforaphane enhanced TRAIL-induced apoptosis through the induction of DR5 expression in human osteosarcoma cells. Carcinogenesis, 27: $1768-1777$.

18. Mor, G., H.H. Fu and A.B. Alvero, 2006. Phenoxodiol, a novel approach for the treatment of ovarian cancer. Curr. Opin. Invest. Drugs, 7 (6): 542-548.

19. Morré, D.J., D. Sedlak, X. Tang, P.-J. Chueh, T. Geng and D.M. Morré, 2001. Surface NADH oxidase of HeLa cells lacks intrinsic membrane binding motifs. Arch. Biochem. Biophys., 392: 251-256.
20. del Castillo-Olivares, A., P.J. Chueh, S. Wang, M. Sweeting, F. Yantiri, D. Sedlak, D.J. Morré and D.M. Morré, 1998. A drug-responsive and protease-resistant peripheral NADH oxidase complex from the surface of HeLa S cells. Arch. Biochem. Biophys., 358: 125-140.

21. Morré, D.J., S. Caldwell, A. Mayorga, L.Y. Wu and D.M. Morré, 1997. NADH oxidase activity from sera altered by capsaicin is widely distributed among cancer patients. Arch. Biochem. Biophys., 342: 224-230.

22. Morré, D.J. and T. Reust, 1997. A circulating form of NADH oxidase activity responsive to the antitumor sulfonylurea N-4(methylphenylsulfonyl)-N'-(4-chlorophenyl)urea (LY181984) specific to sera from cancer patients. J. Bioenerg. Biomembr., 29: 281-289.

23. Cho, N., P.J. Chueh, C. Kim, S. Caldwell, D.M. Morré and D.J. Morré, 2002. Monoclonal antibody to a cancer-specific and drug-responsive hydroquinone (NADH) oxidase from the sera of cancer patients. Cancer Immunol. Immunother., 51: 121-129.

24. Chueh, P.J., C. Kim, N. Cho, D.M. Morré and D.J. Morré, 2002. Molecular cloning and characterization of a tumor-associated, growthrelated and time-keeping hydroquinone (NADH) oxidase (tNOX) of the HeLa cell surface. Biochemistry, 41: 3732-3741.

25. Bird, C., 1999. Direct submission of human DNA sequence from clone $875 \mathrm{H} 3$ (part of APK1 antigen) to GenBank database at NCBI. (Accession no. AL049733).

26. Morré, D.M. and D.J. Morré. 2006. Catechinvanilloid synergies with potential clinical applications in cancer. Rejuvination Res., 9: 45-55.

27. Morré, D.J., N. McClain, L.-Y. Wu, G. Kelly and D.M. Morré, Submitted. Phenoxodiol treatment alters the subsequent response of tNOX and growth of HeLa cells to paclitaxel and cisplatin. In vitro Cell Dev. Biol. Anim.

28. Morré, D.J., 1995. NADH oxidase activity of HeLa plasma membranes inhibited by the antitumor sulfonylurea N-(4-methylphenylsulfonyl)-N'-(4chlorophenyl) urea (LY181984) at an external site. Biochim. Biophys. Acta, 1240: 201-208.

29. Thejass, P. and G. Kuttan, 2006. Antimetastatic activity of sulforaphane. Life Sci., 78: 3043-3050.

30. Fimognari, C., M. Nusse, M. Lenzi, D. Scluscio, G. Cantelli-Forti and P. Prelia, 2006. Sulforaphane increases the efficacy of doxorubicin inmouse fibroblasts characterized by p53 mutations. Mutat. Res., 60: 92-101. 
31. Kamsteeg, J., T. Rutherford, E. Sapi, B. Hanxzaruk, S. Shahabi, M. Flick, D. Brown and G. Mor, 2003. Phenoxodiol - an isoflavene analoginduces apoptosis in chemoresistant ovarian cancer cells. Oncogene, 22: 2611-2620.

32. Brown, D.M., G. E. Kelly and A.J. Husband, 2005. Flavanoid compounds in maintenance of prostate health and prevention and treatment of cancer. Mol. Biotechnol., 30: 253-270.

33. Kelker, M., C. Kim, P.-J. Chueh, R. Guimont, D.M. Morré and D J. Morré, 2001. Cancer isoform of a tumor-associated cell surface NADH oxidase (tNOX) has properties of a prion. Biochemistry, 40: 7351-7354.

34. Griffith, J.S., 1964. Self-replication and scrapie. Nature, 315: 1043-1044.

35. Prusiner, S.B., 1994. Biology and genetics of prion diseases. Annu. Rev. Microbiol., 48: 655-686.

36. Morré, D.J., D.M. Morré and P. Ternes, 2003. Auxin-activated NADH oxidase activity of soybean plasma membranes is distinct from the constitutive plasma membrane NADH oxidase and exhibits prion-like properties. In Vitro Cell Dev. Biol. - Plant, 39: 368-376.

37. Herst, P.M., T. Petersen, P. Jerram, J. Batty and M. Berridge, 2007. The antiproliferative effects of phenoxodiol are associated with inhibition of plasma membrane electron transport in tumour cell lines and primary immune cells. Biochem. Pharmacol., Epub. Aug. 19.

38. Rikiishi, H., F. Shinohara, T. Sato, Y. Sato, M. Suzuki and S. Echigo, 2007. Chemosensitization of oral squamous cell carcinoma cells to cisplatin by histone deacetylase inhibitor, suberoylanilide hydroxamic acid. Int. J. Oncol., 30(5): 1181-1188.

39. Sharma, H., S. Sen and N. Singh, 2005. Molecular pathways in the chemosensitization of cisplatin by quercetin in human head and neck cancer. Cancer Biol. Ther., 4 (9): 949-955.

40. Li, M., Z. Zhang, D.L. Hill, H. Wang and R. Zhang, 2007. Curcumin, a dietary component, has anticancer, chemosensitization and radiosensitization effects by down-regulating the MDM2 oncogene through the PI3K/mTOR/ETS2 pathway. Cancer Res., 67 (5): 1988-1996.

41. Deeb, D.D., H. Jiang, X. Gao, G. Divine, S.A. Dulchavsky and S.C. Gautam, 2005. Chemosensitization of hormone-refractory prostate cancer cells by curcumin to TRAIL-induced apoptosis. J. Exp. Ther. Oncol., 5(2): 81-91.

42. Xin, Y., G. Lyness, D. Chen, S. Song, M.G. Wientjes and J.L. Au, 2005. Low dose suramin as a chemosensitizer of bladder cancer to mitomycin C. J. Urol., 174(1): 322-327.
43. Chen, G. and W.J. Zeller, 1991. Augmentation of cisplatin (DDP) cytotoxicity in vivo by DLbuthionine sulfoximine (BSO) in DDP-sensitive and-resistant rat ovarian tumors and its relation to DNA interstrand cross links. Anticancer Res., 11(6): 2231-2237.

44. Garg, A.K., T.A. Buchholz and B.B. Aggarwal, 2005. Chemosensitization and radiosensitization of tumors by plant polyphenols. Antioxid. Redox Signal., 7(11-12): 1630-1647.

45. Niu, J., X.N. Li, H. Qian and Z. Han, 2007. siRNA mediated the type 1 insulin-like growth factor receptor and epidermal growth factor receptor silencing induces chemosensitization of liver cancer cells. J. Cancer Res. Clin. Oncol., Sept. 28 (Epub ahead of print).

46. Fuessel, S., J. Herrmann, S. Ning, M. Kotzsch, K. Kraemer, U. Schmidt, O.W. Hakenberg, M.P. Wirth and A. Meye, 2006. Chemosensitization of bladder cancer cells by survivin-directed antisense oligodeoxynucleotides and siRNA. Cancer Lett., 232(2): 243-254.

47. Pu, Y.S., T.S. Hsieh, T.C. Tsai, A.L. Cheng, C.Y. Hsieh, I.J. Su and M.K. Lai, 1995. Tamoxifen enhances the chemosensitivity of bladder carcinoma cells. J. Urol., 154(2): 601-605.

48. Folmer, Y., M. Schneider, H.E. Blum and P.Hafkemeyer, 2007. Reversal of drug resistance of hepatocellular carcinoma cells by adenoviral delivery of anti-ABCC2 antisense constructs. Cancer Gene Ther., Aug 17 (Epub ahead of print).

49. Kim, Y.K., Y.J. Song, D.W. Seo, D.W. Kang, H.Y. Lee, D.K. Rhee, J.W. Han, C.M. Ahn, S. Lee and S.N. Kim, 2007. Reversal of multidrug resistance by 4-chloro-N-(3-((E)-3-(4-hydroxy-3methoxyphenyl)acryloyl)phenyl)benzamide through the reversible inhibition of $\mathrm{P}$ glycoprotein. Biochem. Biophys. Res. Commun., 355(1): 136-142.

50. Chen, D., S.H. Song, M.G. Wientjes, T.K. Yeh, L. Zhao, M. Villalona-Calero, G.A. Otterson, R. Jensen, M. Grever, A.J. Murgo and J.L. Au, 2006. Nontoxic suramin as a chemosensitizer in patients: Dosing nomogram development. Pharm. Res., 23(6): 1265-1274.

51. Frederiksen, L.J., R. Sullivan, L.R. Maxwell, S.K. Macdonald-Goodfellow, M.A. Adams, B.M. Bennett, D.R. Siemens and C.H. Graham, 2007. Chemosensitization of cancer in vitro and in vivo by nitric oxide signaling. Clin. Cancer Res., 13(7): 2199-2206. 